\title{
Correction to: Growth of nanoporous high-entropy oxide thin films by pulsed laser deposition
}

\author{
Huiming Guo ${ }^{1}$, Xin Wang ${ }^{1}$, Alexander D. Dupuy ${ }^{1}$, Jullie M. Schoenung ${ }^{1}$, \\ William J. Bowman ${ }^{1,2, a)}$ \\ ${ }^{1}$ Department of Materials Science and Engineering, University of California, Irvine, Irvine, USA \\ ${ }^{2}$ Irvine Materials Research Institute, University of California, Irvine, Irvine, USA \\ a) Address all correspondence to this author. e-mail: will.bowman@uci.edu \\ Published online: 10 February 2022
}

\section{Correction to: \\ Journal of Materials Research (2022) 37:124-135 https://doi.org/10.1557/s43578-021-00473-2}

This article was updated to correct errors in References 17 and 20 introduced during the production process.

Open Access This article is licensed under a Creative Commons Attribution 4.0 International License, which permits use, sharing, adaptation, distribution and reproduction in any medium or format, as long as you give appropriate credit to the original author(s) and the source, provide a link to the Creative Commons licence, and indicate if changes were made. The images or other third party material in this article are included in the article's Creative Commons licence, unless indicated otherwise in a credit line to the material. If material is not included in the article's Creative Commons licence and your intended use is not permitted by statutory regulation or exceeds the permitted use, you will need to obtain permission directly from the copyright holder. To view a copy of this licence, visit http://creativecommons.org/licenses/by/4.0/.

The original article can be found online at https://doi.org/10.1557/ s43578-021-00473-2. 